Article

\title{
Ex-Ante Prediction of Disruptive Innovation: The Case of Battery Technologies
}

\author{
Julian Marius Müller $1, * \mathbb{C}$ and Raphael Kunderer ${ }^{2}$ \\ 1 Business Management, Salzburg University of Applied Sciences, Puch, 5412 Salzburg, Austria \\ 2 School of Business, Economics and Society, Friedrich-Alexander-University Erlangen-Nürnberg, \\ 91054 Erlangen, Germany; raphael.kunderer@fau.de \\ * Correspondence: julian.mueller@fh-salzburg.ac.at
}

Received: 2 September 2019; Accepted: 21 September 2019; Published: 24 September 2019

\begin{abstract}
Battery technologies represent a highly relevant field that is undergoing conversions in the context of, for instance, battery electric vehicles or stationary power storage for renewable energies. Currently, lithium-ion batteries represent the predominant technology that has, however, a considerable environmental impact that could hinder the emergence of sustainable energy systems. Driven by these conversions, several authors claim that potentially disruptive technologies could occur. The concept of disruptive innovation has been highly regarded in research and practice, but has only been successfully regarded from an ex-post perspective. However, without the possibility to establish ex-ante predictions of disruptive innovation, several authors disregard the concept of having significant relevance for practice. In response to this research gap, the present paper attempts to establish an ex-ante prediction of potential disruptive innovation. The method is based on the disruption hazard model by Sood and Tellis, testing seven hypotheses regarding a potential disruption hazard of redox-flow batteries towards lithium-ion batteries. The paper finds that redox-flow batteries could represent a disruptive technology, but this evaluation is limited to an expert evaluation. The authors discuss this finding, as the technical characteristics of redox-flow batteries support its role as a potential disruptive innovation, concluding with implications, limitations as well as suggestions for future research.
\end{abstract}

Keywords: disruptive innovation; ex-ante prediction; battery technologies; energy storage systems; disruption hazard model; redox-flow batteries; lithium-ion batteries

\section{Introduction}

Following the concept of Christensen [1], disruptive technologies have been highly regarded in technology and innovation management. In short, Christensen's concept describes a paradox: A currently less potent technology is more likely to disrupt an incumbent technology than a currently more potent one. For this paradox, several practical examples have been found, as will be explained in Section $2.1[2-5]$.

So far, the concept of disruptive innovation has been criticized for mainly regarding disruptive innovation from an ex-post perspective. Further, only successful examples for disruptive technologies have been investigated in a qualitative manner, not including examples that do not fit into the concept [2]. In response to the call for measurement models for disruptive technologies [6], different concepts for the quantitative evaluation of disruptive innovation have been developed [7-9]. Without the possibility of ex-ante prediction of disruptive innovation, Danneels [2] as well as Govindarajan and Kopalle [10] disregard the concept of disruptive innovation to have a significant practical relevance. Still, ex-ante prediction of disruptive innovation has been scarcely attempted [2,9-11]. 
This paper is dedicated to close this research gap in the field of battery technologies. It applies the hazard model by Sood and Tellis [9], utilizing it for ex-ante prediction (from here on 'prediction'). Several authors suggest the investigation of battery technologies, in which disruptive developments are predicted [12-15]. Further, the field of battery technologies is subject of current investigations regarding the emergence of new technologies. This relates, for instance, to the predominant technology, lithium-ion batteries. The increased need for lithium-ion batteries shows its negative sides, for instance, environmental pollution for raw materials mining, or problems with recycling. This development becomes increasingly relevant through the emergence of battery electric cars and stationary energy storage for regenerative energies or smart energy networks [16-18]. In summary, the current problems with lithium-ion batteries, opposing sustainability goals, could counteract the sustainability goals intended by battery electric cars or smart energy networks. Therefore, the paper attempts to find possible disruptive technologies in the field of battery technologies.

For this purpose, the paper takes an approach from innovation management literature, disruptive innovation. Thereby, leaving the technological perspective on battery technologies, the paper intends to identify battery technologies that could be potentially disruptive from an innovation management perspective, and transfer this finding to the field of battery technologies.

We utilize the expert knowledge of 53 experts from different research institutions within the modified model of Sood and Tellis [9]. The model developed by Sood and Tellis [9] builds on heuristics that characterize disruptive innovation, which is transferred to an ex-ante perspective on disruptive innovation for this paper. Thereby, the paper attempts to transfer characteristics proven to be symptomatic for disruptive innovation in the past to a perspective in the future. The paper finds that, according to the respondents, redox-flow batteries could pose a potential disruptive innovation within the field of battery technologies with a market introduction in about ten years.

This paper is structured as follows: In Section 2, we give a brief overview regarding the concept of disruptive innovation, the hazard model of Sood and Tellis [9], and introduce several battery technologies. Section 3 illustrates our research method, Section 4 the results, whereas Section 5 presents our results, followed by a discussion and conclusion in Section 6 .

\section{Theoretical Background}

\subsection{Disruptive Innovation}

The idea of disruptive innovation by Christensen [1] is based on concepts such as Schumpeter [19], Foster [20] and Henderson and Clark [21]. It addresses the question of successful enterprises failing due to responding inadequately to technological advances [22,23]. In its original understanding by Christensen [1], disruptive technologies initially have an inferior performance at a lower price level than the existing technology, often starting off in a niche market. The existing technology performance overachieves the expectation of mainstream markets through consistent improvements. Furthermore, a low margin in niche markets can be observed for disruptive technologies, hindering the adoption of disruptive technologies by incumbent firms [1,4,24]. Due to these characteristics, disruptive technologies are also termed as low-end disruption in contrast to new-market disruption with completely new value creation networks $[2,4,9,25]$. A third form in contrast to low-end disruption and new-market disruption is termed as an evolutionary or sustaining innovation [1].

Disruptive technologies have shown fatal consequences for incumbent firms in several industries, as technologies with a lower initial performance replace established ones. As a response, incumbent firms' adaptation strategies are limited by four factors. Those often result in their failure to adapt to disruptive innovation, which becomes increasingly difficult to evade [1]: (1) Dependency on investors and customers; (2) niche markets in which disruptive technologies occur are too small for incumbents; (3) non-existing markets cannot be predicted by conventional methods for evolutionary technologies and (4) performance of a technology develops faster than customer demands. Based on these findings, incumbent firms tend to take wrong decisions [24]. Incumbents further tend to scarcely invest in 
the new, potentially disruptive innovation whereas the existing technology receives the majority of resources. On the management level, enterprises often uncover disruptive innovations in time, whereas organizational processes are unable to adapt accordingly [25].

\subsection{Critizism Regarding the Concept of Disrupive Innovation}

While in the first years after Christensen's work in 1997 [1] the publications mainly deal with the causes and the reasons for the emergence of disruptive innovations, the literature of the first years of this millennium increasingly goes to show solutions for dealing with disruptive innovations via companies. This is done in particular with reference to the work Innovator's Solution by Christensen and Raynor [26]. In this phase, Christensen's ideas are increasingly criticized in publications [1,2,4,22].

First, the concept of disruption is not clearly defined and can therefore be interpreted in different ways [2,4]. Second, Christensen [1] leaves open from which point of view disruptions are viewed, for example from a technology, market or customer point of view [9].

Third, the empirical studies by Christensen [1] lack significance and are potentially biased, since he only examined the successful examples of disruptive technologies [2,9]. Numerous counter-examples have been found, in which substitute technologies did not show the lower initial performance attacking the low-end market. Several technologies also immediately attacked the high-end market [2,24].

Fourth, the necessary possibility to identify disruptions ex ante is not given $[2,6,9,10]$. Without the possibility of identifying disruptions even ex ante, Danneels [2] attests that the theory of disruptive innovation has little practical relevance. Taking up this criticism, the methods and, building on them, a selection of research models for predicting disruptive innovations is explained in the following.

\subsection{Methods for the Prediction of Disruptive Innovation}

Due to the high threat imposed by disruptive innovation, several methods for prediction are suggested. Danneels [2] suggests extrapolating historical data as a comparatively simple and intuitive method for predicting future trends. However, extrapolation has two serious disadvantages: First, it is difficult to predict young technologies due to the scarcity or non-existence of historical data. Second, it is difficult to predict a disruptive leap in technology even with well-available data, since an extrapolated development path does indeed reflect evolutionary technology development, but not disruptive leaps. In sum, several researchers argue that even exact data can only extrapolate evolutionary developments rather than predict disruptive innovation $[2,6,10]$.

In current literature, three approaches for analytical models to predict disruptive innovation can be found: Huang and Sošić [7], Chen et al. [8] and Sood and Tellis [9].

The research work of Huang and Sošić [7] develops a model based on the theory of market equilibrium with which the uncertainties arising from a disruptive technology are stochastically taken into account. For this purpose, two companies are compared as models. Company 1 as an established company that is able to develop a new and a conventional product and company 2, a pioneer that can only bring a new product onto the market [7]. Taking into account the competition theory of Bertrand and Cournot, this duopoly analyses whether the continuation of the existing technology or the introduction of disruption is advantageous in each case [7].

While Huang and Sošić [7] primarily deal with the question under which conditions companies decide to enter a disruptive technology, Chen et al. [8] investigate the question of when a disruption arises in which market. They follow the market definition of Christensen and Raynor [26], which distinguishes between the new markets and the existing markets. In both markets, the authors identify the critical point in time that is important for established companies, namely the time at which disruptive innovation gains a foothold. The time of disruption in a new market is named D-Day, the time of disruption in a mainstream market V-Day. The prediction model is based on the bass diffusion model, which predicts the time of first purchase and the maximum sales of a product based on historical sales data. The difference is formed from the product performance, which represents the customer value and the willingness of the customer to pay [8]. 
As a third method, the Hazard Model by Sood and Tellis [9] considers the risk for disruptive innovation, presenting possible indicators for its occurrence. We chose the model of Sood and Tellis [9] as being most suitable for investigating the potential for disruptive innovation in battery technologies for two reasons: First, a possible disruptive innovation in the field of battery technologies has not been uncovered, as the model of Huang and Sošić [7] mainly focuses on disruptive innovation on a company level. Second, the model of Chen et al. [8] requires data such as sales data and customer willingness to pay, for which data is available in business-to-customer, but not in business-to-business markets, which is the primary market for battery technologies.

Sood and Tellis [9] confirm their hypothesis in seven markets with 36 technologies utilizing historical data. The technologies investigated include electric lighting, data storage, printing, computer monitors, music recording and painkillers as well as data transmission.

In the third part, Sood and Tellis [9] develop a model based on the correlated hazard model [27], which is derived from the proportional hazard model by Cox [28]. Cox-regression hereby describes a concept to determine the time until a certain event occurs [29], whereas hazard is the risk of a certain event occurring. Mostly, these events are termed as fault or failure, often referring to a patient's death or employee strikes [30]. Lillard [31] developed a way to investigate multidimensional hazard processes, incorporating time-dependent as well as time-independent or exogenous covariates. For their model, Sood and Tellis [9] integrate the performance and maturity of a market as time-dependent factors, whereas the market entrance sequence or the form of a market attack are used as exogenous covariates. The model equations are described for both firm disruption as well as for technology disruption. For the latter, the variable for the form of attack is omitted, as technology disruption is characterized by a low-end market attack. The following two model equations describe the model by Sood and Tellis [9] ( $\alpha, \beta, \lambda$ represent parameters, while the variables are described below):

$$
\begin{gathered}
\ln h_{i t}^{T}=\beta_{0}+\beta^{\prime}{ }_{1} T_{1 t}+\beta_{2} E_{i}+\beta_{3} S_{i}+\beta_{4} C_{i}+\beta_{5} O_{i}+\beta_{6} P_{i t}+\lambda_{i t}^{T} . \\
\ln h_{i t}^{F}=\alpha_{0}+\alpha^{\prime}{ }_{1} T_{2 t}+\alpha_{2} E_{i}+\alpha_{3} L_{i}+\alpha_{4} S_{i}+\alpha_{5} C_{i}+\alpha_{6} O_{i}+\alpha_{7} P_{i t}+\lambda_{i t}^{F} .
\end{gathered}
$$

E Pioneer, it equals 1 if the technology performed was introduced by a pioneer, not active in this industry so far. Else, it equals 0 .

L Lower attack, it equals 1 if the technology performed a lower attack at the time of market entrance. In other cases, it equals 0 .

S Firm size, it equals 1 if the firm introducing the technology was a small enterprise, exclusively founded for introducing the technology at market entrance. In other cases, it equals 0.

C Price, it equals 0 if the new technology was cheaper at the time of market entrance than the existing technology. Otherwise, it equals 0.

O Order of market entrance of the new technology.

$\mathrm{P} \quad$ Change of technological performance in comparison to the preceding year, in percent.

$\mathrm{T} \quad$ Time until market entrance of technology.

\subsection{Battery Technologies}

Batteries represent the oldest form of electrical energy storage [32]. Contemporary challenges regarding lithium-ion batteries include low energy density, high costs, long charging times and changing capacities related to the outside temperature as well as weight and low durability [33-35]. From a production point of view, lithium-ion batteries have high resource requirements, for instance cobalt, whereas pollution of water and entire landscapes is a major problem that is currently discussed. Recycling of lithium-ion batteries is a further environmental challenge, while several incidents of thermal runaway, i.e., lithium-ion batteries catching fire are reported due to mechanical harm, overcharging or discharging [27,36-39].

We claim that battery technologies represent a valid field of investigation, as especially the latter named lithium-ion batteries, which replaced nickel-metal hydride batteries (NiMH) in the last years, are not at the end of their technological capabilities [40,41]. 
An increasing demand is predicted for the future through battery-powered electric cars, as batteries have so far mainly been required in consumer electronics [42-44]. Along with high costs and weight, the beforehand mentioned durability of batteries is a hindering factor for implementation. A second field of application for batteries is emerging through the introduction of renewable energies, such as photovoltaic or wind power, which underlie fluctuations in energy generation and demand of consumers [45,46]. Here, especially energy density and economic viability are named as performance indicators to be improved in order to be implemented within smart grids. Further, a first application in consumer electronics or car batteries can be used in stationary energy storage later on $[47,48]$.

For car batteries, up to 18 relevant characteristics that determine its performance are named [44,49], also referring to secondary components attached to the battery itself. To identify a common performance indicator for comparison [1,9], we decided for the performance indicator of energy density. It describes the capacity in volume or weight and is most commonly measured in Wh per $\mathrm{kg}$. Weight is the most crucial factor for mobile applications in consumer electronics as well as for the automotive sector, whereas especially the latter is expected to generate a high demand for batteries in the next years [18]. Therefore, a high energy density is a perquisite for successful implementation in the future $[49,50]$.

To integrate the field of battery technologies within the model of Sood and Tellis [9], we identified the type of enterprise (E), lower attack (L), firm size (S) and price (C) for the most common existing battery technologies for mobile and stationary use [47-49,51]. From these sources, we also included the energy density of different battery technologies over time. The results are summarized in Table 1 and Figure 1.

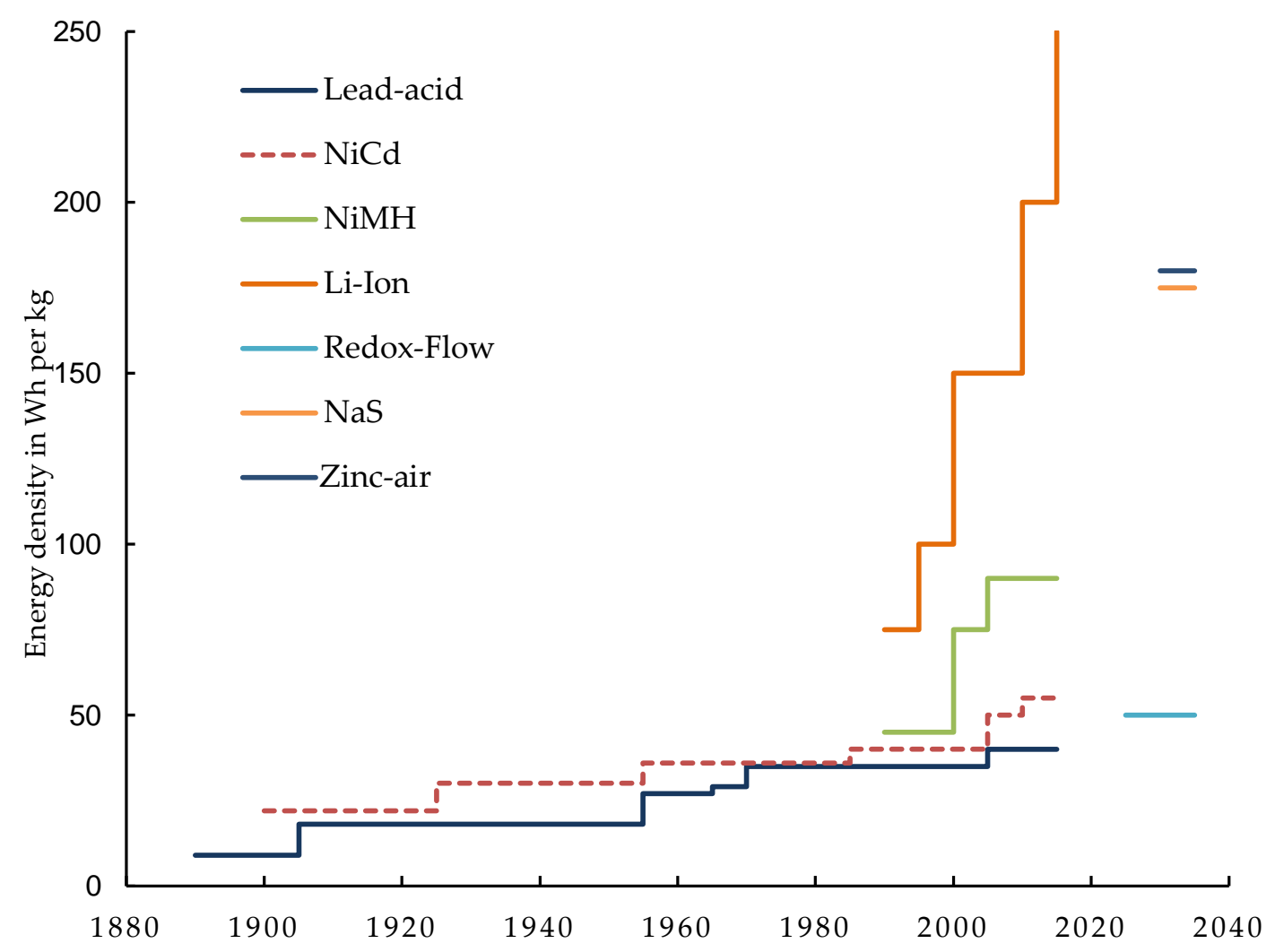

Figure 1. Development of energy density of different battery technologies. 
Table 1. Historical data regarding market entrance of battery technologies

\begin{tabular}{cccccc}
\hline Battery Technology & $\begin{array}{c}\text { Type of } \\
\text { Enterprise (E) }\end{array}$ & $\begin{array}{c}\text { Lower Attack } \\
\text { (L) }\end{array}$ & $\begin{array}{c}\text { Firm Size } \\
\text { (S) }\end{array}$ & $\begin{array}{c}\text { Price } \\
\text { (C) }\end{array}$ & $\begin{array}{c}\text { Survival Time } \\
\text { in Years (T) }\end{array}$ \\
\hline Lead-acid & 1 & - & 1 & - & 13 \\
Nickel-Cadmium (NiCd) & 1 & 0 & 1 & 0 & 89 \\
Nickel-Metal-Hydride & 1 & 0 & 1 & 0 & 1 \\
(NiMH) & 0 & 0 & 0 & 0 & 37 \\
\hline
\end{tabular}

We did not include lithium-air batteries in Figure 1, as the potential energy density is expected to be significantly higher than for lithium-ion batteries, potentially up to 5-15 times higher [52]. However, this technology was included in our empirical research. Further, redox-flow, sodium sulfur (NaS) and zinc-air batteries were included with their expected energy density and market occurrence [52].

Except for lithium-ion batteries by Sony, all commonly used battery technologies were introduced by pioneers, which corroborates the findings of Christensen [9]. In all cases, new battery technologies led to a higher energy density, as shown in Figure 1. Therefore, we could assume that never before has low-end market disruption taken place in the field of battery technologies [1,9].

Sodium-sulfur, zinc-air batteries as well as lithium-air show an energy density that could be at the same level or even higher than that of lithium-ion batteries when entering the mass market. Therefore, sodium-sulfur and zinc-air batteries did not possess the characteristics of disruptive innovation, but could simply outperform lithium-ion batteries. As a result, only redox-flow batteries could be a potential disruptive innovation $[1,9]$. This is as their energy density was significantly lower than the existing battery technology, lithium-ion batteries. Redox-flow batteries therefore pose a potential threat for a low-end attack in the battery industry.

Furthermore, Dunn et al. [36] state a simple structure for redox-flow batteries, which allows external processing of electrolytes in contrast to other battery technologies. This entails the possible capability to replace the recharging process by a 'refueling' process of electrolytes. As a result, cars with redox-flow batteries could be 'refueled' much faster rather than 'recharged' [50]. Consequently, the potential for improved usability, as a second indicator for disruptive innovation arises. The demand for a disruptive innovation could hereby be augmented by the increased importance of stationary energy storage, possibly boosted by renewable energy usage. Here, energy density for stationary applications is not a primary target [44], but could lead to disruption as this performance indicator is not requested by the customer in the first place [1].

Further favorable characteristics of redox-flow batteries are their applicability for energy storage of renewable energy sources and their favorable environmental assessment. For instance, redox-flow batteries' technical characteristics make them suitable for load leveling, peak shaving and seasonal energy storage. In combination with renewable energy sources such as wind or photovoltaic energy, which show deviations in power generation due to changing weather conditions, several authors ascertain redox-flow batteries to be most suitable among current battery technologies. This is since redox-flow batteries with particularly favorable characteristics for photoelectric charging exist, i.e., with a favorable matching of energy levels between redox couples and the photoelectrode. Further, organic-based redox couples show a low-cost potential for the future [53,54].

Therefore, we regard redox-flow batteries as a potential disruptive innovation for lithium-ion batteries in the following empirical research setting.

\section{Method}

\subsection{Hypothesis Development}

In a first step, Sood and Tellis [9] develop seven hypotheses for disruptive innovation. Three out of seven hypotheses consider the appearance of the disruptive innovation on the market, whereas the 
latter four hypotheses address the risk of disruptive innovation emergence and the indicators that increase the hazard for disruption.

The relatedness for battery technologies for hypotheses $\mathrm{H} 1$ to $\mathrm{H} 3$ is grounded in the fact that battery technologies have always been introduced by new firms, up to the introduction of lithium-ion batteries, which were introduced by Sony. Therefore, by testing H1 to H3, we intend to shed light on who might possibly introduce a new disruptive technology on the market. For hypotheses H4 to H7, the paper follows the heuristics developed by Sood and Tellis [9] for disruptive innovations and tests them for battery technologies.

Christensen [1], based on his empirical study of the hard disk industry, has found that most companies have pioneered and developed disruptive technologies. Based on this investigation, the concept of disruptive innovation, especially low-end disruption, is mostly associated with pioneers [2]. To verify this, Sood and Tellis [9] put forward the following hypothesis:

Hypothesis 1 (H1). Technologies using a lower attack (potentially disruptive) come primarily from entrants.

According to Christensen [1], evolutionary technology leaps originate almost exclusively from established companies. Christensen and Raynor [26] justify this as follows: Since evolutionary technologies offer better performance, they are aimed at customers in the upper market segment. In contrast to the pioneers, the established company is in a better position to use existing sales channels and thus achieve higher margins, which is why these ultimately prevail. As a supplementary statement, Govindarajan and Kopalle [10] add that established companies are hardly willing to withdraw resources from successful technologies and invest in potentially disruptive ones. Analogous to the statement of $\mathrm{H} 1$, the strict connection between evolutionary technology and established companies is criticized. Here, one can mention the example of Intel, which introduced a cheaper and less powerful series of processors with the Celeron [4]. Nevertheless, Sood and Tellis [9] hypothesize the following:

Hypothesis 2 (H2). Technologies using an upper attack (sustaining breakthrough) come primarily from incumbents.

The third hypothesis on technology entry also describes a central statement by Christensen [1] on disruptive technologies, claiming that disruptive innovations are usually cheaper and target the lower market segment. Therefore, the profit margin for disruptive technologies is also assumed lower. However, companies can minimize costs in this situation if the variety of products is reduced through the targeted operation of niche segments. Taking these aspects into account, Sood and Tellis [9] propose the following hypothesis:

Hypothesis 3 (H3). Technologies using a lower attack (potentially disruptive) are priced lower than dominant technologies at entry.

As already mentioned, the last four hypotheses deal with the risk of disruption or hazard of disruption. The hazard model is used to check to what extent the severity of the disruption increases or decreases under certain circumstances. Hypothesis 4, like H1 and H2, examines the company type of a disruption. The question is asked which type of company is more likely to participate in a disruption [9]. According to Christensen [1], pioneers are defined by the fact that, in contrast to established companies, they drive disruptions in the first place. Govindarajan and Kopalle [6] argue that established companies are quite capable of enforcing disruptive technologies if their corporate culture is oriented towards them. One reason why established companies have little interest in disruptive technologies is that they mostly underestimate the danger $[9,25]$. This leads to the following hypothesis:

Hypothesis 4 (H4). The hazard of disruption is higher from an entrant than from an incumbent. 
As a further aspect, established companies are usually convinced that these types of technologies are unattractive for the mainstream market due to their poorer performance [9]. In doing so, the established companies neglect the fact that a disruption occurs when the properties or performance of the continuously improved product are no longer demanded by the mass market) $[1,10]$. Conclusively, Sood and Tellis [9] propose the following hypothesis:

Hypothesis 5 (H5). The hazard of firm or demand disruption is higher if a new technology uses a lower attack.

Hypotheses $6 \mathrm{~A}$ and $6 \mathrm{~B}$ also deal with the type of company that introduces a disruptive innovation. Abernathy and Utterback [55] associated disruptive innovation with small enterprises or start-ups, as they are able to react quickly and to effectively exploit growth in small markets [1]. Large companies are, however, certified to benefit from a technological standstill [56], as they can thus defend their strong market shares [1]. Consequently, Sood and Tellis [9] suggest the following hypothesis:

Hypothesis 6A (H6A). The hazard of disruption is higher if a new technology is introduced by a small firm.

However, some claim that the role of pioneers in innovation development is often over-estimated [57] and that large business units in particular have advantages in the development of new technologies due to their superior financial strength and management resources [52]. Hill and Rothaermel [58] worked out in an empirical study that the majority of disruptive technologies are initiated by established companies. On the basis of these arguments, Sood and Tellis [9] formulate a counter-hypothesis:

Hypothesis 6B (H6B). The hazard of disruption is lower if a new technology is introduced by a small firm.

This train of thought goes back to the fact that the new hard disks examined by Christensen (1997) [1] were cheaper, faster and more reliable. The cheaper price is indeed typical for disruptions but not necessarily necessary [2]. Therefore, Sood and Tellis [9] suggest the following hypothesis:

Hypothesis 7 (H7). The hazard of disruption is higher if a new technology is lower priced than the dominant technology at entry.

\subsection{Operationalization and Data Colletion}

Attempting to utilize the disruption hazard model [9] for prediction of battery technologies, we only investigate a technology disruption rather than firm disruption. The research approach aims to include expert opinions and heuristics within the research design. In a first step, we attempt to verify our results obtained by experts by performing an ex-post analysis that regards the replacement of $\mathrm{NiMH}$ batteries through lithium-ion batteries alongside the prediction of a potential disruption for battery technologies.

In contrast to Sood and Tellis [9], who investigated the hazard for disruption with a multilevel statistics software named 'applied maximum likelihood' (aML) [59], we used the hazard model by Cox [37]. Despite a comparable functionality, but also a lower efficiency of the underlying algorithm [30], we chose this approach as the definition of a baseline hazard is not required. Attempting an ex-ante analysis of disruptive innovation, we found this baseline hazard unsuitable to be predicted by expert surveys. The basic model by Cox [37] is defined as follows:

$$
h(t \mid z)=h_{0}(t) \exp \{g(\beta, z)\} .
$$

$h_{0}(t)=$ baseline hazard;

$\beta=$ vector with regression coefficient. 
By integrating the variables defined in Section 2, we came to the following equation for the hazard of disruption, relating to the temporal occurrence of disruption $(t)$ :

$$
h(t \mid i)=h_{0}(t) \exp \left(\beta_{1} E_{i}+\beta_{2} S_{i}+\beta_{3} C_{i}+\beta_{4} P_{i}\right) .
$$

After gathering personal data from the respondents referring to their position and experience with battery technologies, we addressed hypothesis 1 to 3 within our first set of questions. The context chosen was why lithium-ion batteries replaced the previous battery technologies in terms of relative price $(\mathrm{C})$, lower attack $(\mathrm{L})$ and technological performance $(\mathrm{P})$. Furthermore, we addressed whether lithium-ion batteries had been successfully introduced by pioneers $(E)$, which we paraphrased with enterprises that had not been active in this sector [9]. Next, we determined the influence of the firm size (S), i.e., enterprises that had been established exclusively for introducing the technology [9]. The experts could answer these questions as dummy variables with yes or no, which is kept throughout the questionnaire [60]. Lastly, we asked for the expected rate at which energy density would increase in the next ten years $(\mathrm{P})$. The detailed questions and how those were operationalized in the model can be obtained from Tables A1-A6 in the Appendix A.

The second part of the questionnaire asked why redox-flow batteries could prevail over Li-ion batteries in the future. The same questions from the questionnaire block of the $\mathrm{Li}$-ion batteries were repeated for redox-flow batteries. On the one hand, this should make it possible to compare the questions from the question blocks and on the other hand enable the experts to answer them quickly and easily. Compared to the first questionnaire, only a supplementary question was inserted. It was asked in how many years the commercial introduction of redox-flow batteries was expected. This question was used to check the time to market entry and thus to obtain a survival time for the hazard model. In order to check whether redox-flow batteries really were the next commercialized technology after Li-ion batteries, the time of the market launch (T) of high-temperature, lithium-air and zinc-air batteries was asked in the last questionnaire block. The word disruption was intentionally avoided here, in order to avoid influencing the results. However, as pointed out by several researchers, market entrance and disruption must not necessarily be at the same time [7-9]. All three questions were openly asked, as with the previous open questions, a numerical value was freely entered here.

As the questions were largely preset by Sood and Tellis [9], we performed a pretest with four experts to ensure understandability of the questions in the context of battery technologies. Further, the entire study was advised and supported by a German automotive Original Equipment Manufacturer (OEM). Table A1 in the Appendix A shows the detailed questionnaire used in the empirical study.

To gather empirical data for our questionnaire, we sent invitations via email to experts from research institutions and enterprises active in battery research worldwide in July 2017. The members of the German Federal Association of Energy Storage Companies, California Energy Storage Alliance (CESA), China Energy Storage Alliance (CNESA), European Association for Storage of Energy (EASE) and Energy Storage Association (ESA) were approached. Further, we invited participants from the leading trade fairs for energy storage, such as Energy Storage North America 2016 or Energy Storage Europe 2016. From 665 experts contacted, we gained 87 responses, resembling a response rate of about 13 percent. Out of 87 responses, 34 were removed due to incomplete answers, leading to a final sample of 53 enterprises.

Out of 53 participants, 48 derived from Europe, four from the USA and one respondent did not state his or her origin. Regarding their professional background, 17 out of 53 participants were from state or industry associations, 14 from R\&D departments as well as laboratories, 11 were battery manufacturers, 10 were battery applicants, three were from component suppliers, a single respondent was from battery sales and one was from university (multiple answers possible). Referring to battery usage fields, 37 of 53 respondents concerned battery electric vehicles, 36 worked with stationary applications of batteries and seven were active in consumer usage of batteries (multiple answers possible). 


\section{Results}

Table 2 subsumes the results of the hypothesis tested. The descriptive results can be obtained from Table A1 in the appendix.

Table 2. Results of hypotheses tested.

\begin{tabular}{|c|c|c|}
\hline Topic & Hypothesis & Result \\
\hline \multirow[t]{3}{*}{ Technological entry } & $\begin{array}{c}\text { (H1) Technologies using a lower attack (potentially disruptive) } \\
\text { come primarily from entrants. }\end{array}$ & Supported \\
\hline & $\begin{array}{l}\text { (H2) Technologies using an upper attack (sustaining } \\
\text { breakthrough) come primarily from incumbents. }\end{array}$ & Supported \\
\hline & $\begin{array}{l}\text { (H3) Technologies using a lower attack (potentially disruptive) } \\
\text { are priced lower than dominant technologies at entry. }\end{array}$ & Supported \\
\hline \multirow[t]{5}{*}{ Hazard of disruption } & $\begin{array}{c}\text { (H4) The hazard of disruption is higher from an entrant than } \\
\text { from an incumbent. }\end{array}$ & Not Supported \\
\hline & $\begin{array}{c}\text { (H5) The hazard of firm or demand disruption is higher if a } \\
\text { new technology uses a lower attack. }\end{array}$ & Not Supported \\
\hline & $\begin{array}{c}\text { (H6A) The hazard of disruption is higher if a new technology } \\
\text { is introduced by a small firm. }\end{array}$ & Not Supported \\
\hline & $\begin{array}{c}\text { (H6B) The hazard of disruption is lower if a new technology is } \\
\text { introduced by a small firm. }\end{array}$ & Not Supported \\
\hline & $\begin{array}{l}\text { (H7) The hazard of disruption is higher if a new technology is } \\
\text { lower priced than the dominant technology at entry. }\end{array}$ & Supported \\
\hline
\end{tabular}

To test hypotheses one to three, the results were analyzed using a two-dimensional cross Table 3. If battery technologies are considered separately, the following picture emerges: The question whether lithium-ion batteries would have prevailed over $\mathrm{NiMH}$ batteries due to the higher energy density was answered in the affirmative by 46 out of 52 (88.5\%) of the respondents. In contrast, 36 out of 49 (73.5\%) respondents believed that redox-flow batteries would attack the lower market segment. The results of the lithium-ion batteries and redox-flow batteries were summarized in a cross Table 3 in order to be able to make a qualified statement for both the lower attack and the upper attack. As with Sood and Tellis [9] several potentially disruptive technologies were compared.

Table 3. Type of enterprise and price.

\begin{tabular}{|c|c|c|c|c|}
\hline & \multicolumn{2}{|c|}{ Lower Attack } & \multicolumn{2}{|c|}{ Upper Attack } \\
\hline & Frequency & Percentage & Frequency & Percentage \\
\hline \multicolumn{5}{|l|}{ Type of enterprise } \\
\hline Pioneer & 22 & $52.4 \%$ & 32 & $61.5 \%$ \\
\hline Established enterprise & 20 & $47.6 \%$ & 20 & $38.5 \%$ \\
\hline Total & 42 & $100.0 \%$ & 52 & $100.0 \%$ \\
\hline Chi-Quadrat (Pearson) & \multicolumn{4}{|c|}{0.797} \\
\hline$p$-value & \multicolumn{4}{|c|}{0.372} \\
\hline \multicolumn{5}{|l|}{ Price at market entrance } \\
\hline Higher price & 29 & $69.0 \%$ & 45 & $88.2 \%$ \\
\hline Lower price & 13 & $31.0 \%$ & 6 & $11.8 \%$ \\
\hline Total & 42 & $100.0 \%$ & 51 & $100.0 \%$ \\
\hline Chi-Quadrat (Pearson) & \multicolumn{4}{|c|}{5.216} \\
\hline$p$-value & \multicolumn{4}{|c|}{0.022} \\
\hline
\end{tabular}

Regarding $\mathrm{H} 1$ and $\mathrm{H} 2$, we found that 52.4 percent of experts expected a lower attack by pioneers, whereas 47.6 percent assumed an attack from established enterprises. We could not find any significant correlation between the form of attack and form of enterprise, which corroborates extant findings [9]. The frequency distribution among our sample supports Danneels [2] and opposes Christensen [1]. Similarly, we could not confirm the claim of Christensen [1] that established that enterprises primarily attack the upper market segment, as 61.5 percent of experts stated that upper attacks derived from 
pioneers. These results corroborate Sood and Tellis [9] who found a quite similar number of 58 percent in their study.

Concerning H3, only 31 percent of experts expected a cheaper technology introduced successfully onto the market as less potent. We hereby found a significant correlation $(p=0.022)$ between price and capability, opposing Christensen [1] and supporting Sood and Tellis [9], who found a ratio of 88 to 12 percent. Our experts were therefore in-line with historical data obtained regarding lithium-ion batteries.

For hypothesis 4 to 7, we used Cox-regression modeling to test whether the covariates E, S, C and P shorten the timespan until disruption. We applied the data obtained regarding redox-flow batteries, as our experts considered redox-flow as a potential low-end attack, which is still before market entrance. Therefore, the Cox-model with the consideration of the time until market introduction could be applied. Table 4 shows the results for the Cox-regression performed to determine the hazard for disruption [9].

Table 4. Hazard of disruption from redox-flow batteries (Cox-regression).

\begin{tabular}{cccc}
\hline & Coefficient B & Exp (B) & $p$-Value \\
\hline Incumbency (E) & 0.026 & 1.026 & 0.949 \\
Firm size (S) & -0.521 & 0.594 & 0.239 \\
Price (C) & 0.359 & 1.432 & 0.371 \\
Change of technological & -0.11 & 0.989 & 0.083 \\
performance in percent (P) & & 199.009 & \\
Log-Likelihood & & \\
\hline
\end{tabular}

We could not confirm $\mathrm{H} 4$, claiming that disruptive innovations were predominantly introduced by pioneers. Regarding the results of the regression, we found that the timespan until potential disruption was not altered $(B=0.026$, Exp $(B)=1.026)$. This result opposes the findings of Sood and Tellis [9], who state that established enterprises increase hazard of disruption.

$\mathrm{H} 5$, claiming that lower attack increases the risk of disruption, could not be concluded from our study, as we only investigated technology disruptions, but not firm or demand disruptions.

For H6A and H6B, only 35.7 percent of experts expected lower attacks from small, newly founded enterprises especially for this purpose. We found that the disruption hazard was halved for especially founded enterprises $(B=-0.521, \operatorname{Exp}(B)=0.594)$. Supporting several authors $[9,52,58]$, our experts state large enterprises to be the predominant drivers for disruptive innovations in the field of battery technologies. However, it has to be noted that Sood and Tellis [9] only confirm this hypothesis for firm disruption, not for technology disruption.

For H7, we found that a lower price increases disruption hazard by the factor of $1.4(\mathrm{~B}=0.359$, $\operatorname{Exp}(B)=1.432)$. This means that our experts expected a lower attack to have a higher price at the beginning. A lower price also increases disruption hazard according to Sood and Tellis [9]. For the energy density $\mathrm{P}$, we could not find an influence on the time of market entrance of redox-flow batteries.

In summary, we confirmed hypothesis 1 to 3 for the field of battery technologies. For hypothesis 4 to 7 , we could only confirm $\mathrm{H7}$ that a lower price increases the probability of disruption regarding battery technologies.

\section{Discussion}

The assumption that redox-flow batteries will be commercially successful in the near future is supported by the fact that the technology has been researched since the 1960s [36], and that the battery is considered advantageous especially in the stationary area [33]. Even though $\mathrm{NaMeCl} 2$ batteries for high-temperature batteries are already produced by one manufacturer [35], it is not yet possible to speak of a commercial market breakthrough. The experts' assessment of zinc-air and lithium-air batteries coincides with the state of research, as the chemical processes cannot yet be fully controlled [35]. 
The performance assessment of lithium-ion batteries having a lower energy density, which is shared by almost a quarter of respondents, is difficult to understand, as the energy density of redox-flow batteries is currently more than $50 \%$ lower [47]. As it is often the case for redox-flow batteries [59], only the energy density of the electrolyte and not of the entire system may have been assessed for redox-flow batteries. On the other hand, for example [56] states that redox flow systems in stationary use are up to $50 \%$ cheaper than Li-ion systems.

Further, it is striking that if it is assumed that the first commercial production of Li-ion batteries was carried out by Sony [36], this fact seems to be unknown by 37 percent of respondents. This can be explained, for example because the areas of activity were mainly in the area of e-mobility and stationary storage, where companies other than Sony are seen as the first in the market. Therefore, a market-specific investigation is required for future research advances in this direction.

Both research into Sood and Tellis' 36 markets [9] and four different battery technologies have shown that an attack on the lower market segment is comparatively unlikely. Against the background that Christensen (1997) [1] has identified a multitude of low-end disruptions within a very short time, using of the hard disk industry as the subject of his investigation, the occurrence of disruptive innovation proves to be industry-specific as well as technology-specific [9].

In the more than 100-year history of energy storage, no technology with an initial lower energy density has become established. However, there is no empirical data on interruptions in this area. With the commercial introduction of redox flow batteries, which is expected by the experts surveyed within the next ten years, a technology with poorer performance could prevail for the first time.

As with H1, no significant correlations between established companies and evolutionary technology developments were identified for $\mathrm{H} 2$ either. However, it is unclear from which type of company the redox flow battery will ultimately be introduced. In contrast to Christensen's [1] findings that $80 \%$ of low-end disruptions in the hard disk industry come from pioneers, both the ex-post analysis of Sood and Tellis [9] and the expert survey give an unclear picture, so that H1 could not be confirmed. Furthermore, the investigation of $\mathrm{H} 4$ does not show any connection between the risk of disruption and the nature of the company. However, the results also deviate from statements to the contrary, stating that disruptions mainly originate from established companies [21,22].

However, the studies do not reveal whether the term "pioneer" should be interpreted more in terms of a newly founded company or a company outside the industry. If the term pioneer is understood as a newly founded company, in contrast to the present study, the recognition that newly founded companies reduce the risk of disruption could serve as an explanation. An explanation for the results of both $\mathrm{H} 1$ and $\mathrm{H} 2$ as well as $\mathrm{H} 4$ could be that the nature of the company plays less of a role than the fact of what decisions are made in management. This assumption is also confirmed, which makes corporate success dependent on the efficiency of resource use, which assumes that a company is successful in a disruptive environment when it specifically withdraws capital from existing products and invests in new technologies [57]. In contrast to the nature of the company, the price of the product showed that there is a correlation between the nature of the attack and the price level.

A possible explanation for the results obtained could be the idea of the low-end fringe-market encroachment [4]. A niche market in which redox-flow batteries could become established is stationary applications, since energy density is only of secondary importance here and the costs over the entire service life are relevant rather than the price [36]. Starting from the niche market of stationary energy storage devices, redox-flow batteries could become established in the lower price segment of other application areas in the coming decades, as there is already promising research on significant increases in energy density [36]. In this context, however, another scenario is conceivable, namely that the market for stationary energy storage units is developing into a mass market itself and thus the performance parameters that were initially relevant for the niche market are now becoming suitable for mass production. This scenario would also be in line with Schmid and Druehl's niche market concept [4]. At first glance, the review of $\mathrm{H} 7$ seems to have led to the opposite, namely that a lower price increases the risk of disruption. Here too, the idea of the niche market disruption offers an explanatory approach. 
Thus it is possible that a technology that is initially positioned in a niche market is initially even more expensive, but at the time of entry into the mainstream market that has a lower price due to economies of scale [4]. In summary, both the findings of Sood and Tellis [9] and the present study show that it is possible to predict a disruption about the price level of a technology rather than about the nature of the company. If we look at the literature analysis carried out, we see that a large number of studies deal with the type of company that will experience a disruption rather than with the price. Therefore, future research on the price level in connection with disruptions is recommended, also in the area of battery storage.

As a further aspect, the embeddedness of batteries in smart energy networks has to be regarded, an aspect that is also raised in disruptive innovation literature in general or in adjacent fields [61-66]. Especially the combination of stationary usage, refueling of batteries in automotive applications, and the emergence of possible disruptions from other industries has to be mentioned in this context [67]. In all cases, a possible lead user or lead application is required in order to support the emergence of disruptive innovation [68].

Hence, the interrelations between possible applications of redox-flow batteries need to be integrated into future cell and systems design $[69,70]$. Although the identification of disruptive innovation theory on battery technologies is accompanied by several technological factors, its characteristics highlight a possible disruptive technological innovation that can be accompanied by technological research. A self-reinforcing effect is to be expected, namely that future disruptive developments such as renewable energies or the electrification of mobility $[15,18]$ due to changed technology requirements and economies of scale through increased demand will encourage the development of new battery technologies.

\section{Conclusions}

\subsection{Theoretical and Managerial Contribiton}

This paper was among the first that attempts creating predictions for disruptive innovation [2]. We included expert opinions for this prediction, as several authors disregard the interpolation of performance data to be predictive of disruption $[2,7,8]$.

Overall, several claims of Sood and Tellis [9] can be confirmed for ex-ante analysis of disruptive innovation. Therefore, this paper contributes to the understanding of disruptive innovation, which is vital for the survival of industries [1]. As 10 years is considered enough time to react, this insight can be an important contribution for the battery industry $[15,18]$. The development speed for new battery technologies will possibly increase on the background of renewable energies and battery electric vehicles.

The literature analysis has shown that the concept of disruptive innovation could be interpreted in many ways and was by no means firmly defined. The interpretations ranged from a predominantly qualitative definition such as Christensen [1] to the other extreme, a qualitative description as carried out by Sood and Tellis [9]. This range of definitions presents qualitative studies with the challenge that comparisons, especially to the statements of Christensen [1], must always be carefully weighed up. Despite the weak points, Sood and Tellis [9] close a research gap that had already been pointed out years before [2,10]. Particularly noteworthy here is the application of the model used by Lillard [31] for analyzing the fertility of married couples to disruptive innovations. At this point, the present work has been taken up in order to determine the risk of discrimination with the help of the very popular Cox regression model, which is mostly used in medicine to analyze the death of patients. The Cox model has shown to what extent the time it takes for a disruption to occur depends on individual variables such as the company or the price. Since the existence of companies, if not even entire industries, depends on this topic [1], all identifiable clues should be used for the detection of disruptions. The expert survey can offer a solution in contrast to the interpolation of existing performance data $[2,7,8]$, but also has several limitations, as described in the following. 


\subsection{Limitations}

The usage of an expert survey has several limitations. First of all, the experts' opinion might be subject to several personal biases, for instance self-selection of a preferred technology or that the experts are active in. Although the survey design did not allow for interpretation except for the expected time to market and performance increase, and standard deviations were on an acceptable level (see Tables A5 and A6 in the Appendix A), this limits the results notably. Therefore, the experts' opinion could only be seen as a first hint for a possible disruption, not actually predicting disruption itself.

Second, since battery technologies are used in different applications, this also limits the generalizability of results. The result about experts disagreeing on who the introducer of lithium-ion batteries was in different industries limited the results significantly. The experts surveyed also noted in particular that there were a large number of markets in the energy storage sector, which, however, focused on very different performance criteria.

Third, it has to be mentioned that only 53 questionnaires were used. Therefore, several hypotheses could not be confirmed based on low reliability scores, which could have been proven with a larger sample.

In summary, the challenge of the present work was to develop a schema with which it was possible to check a prediction model without ex-post data or the interpolation of existing performance data. For this reason, the opinion of experts in the field of battery storage was used. Although presenting a novel approach, this also raised several challenges that result from integrating expert knowledge. Therefore, we want to stress out that the results could only serve as a thought-provoking approach for future research, but not predict a possible disruptive innovation without further verification. In order to address the limitations encountered, several avenues for future research are suggested in the following.

\subsection{Suggestions for Future Research}

First of all, the findings in the field of battery technologies must be separated for different areas of application. In view of Danneels' [2] recognition that technologies can be disruptive in one market and incremental in another, it would make sense to investigate battery storage technology on a market-specific basis.

Second, a targeted search should be made for early indicators that indicate disruptions in advance in order to check them with the known prediction models. The integration of expert opinions might be one, but should not be the only method used in a future attempt, as it has several limitations described above.

Third, in this paper as well as in Sood and Tellis [9], the concept of disruption was essentially reduced to the lower performance compared to existing products. Christensen [1] mentions efficiency as a central indicator of disruptions, but at the same time adds further characteristics of disruptions that have not been investigated in this paper.

In summary, the paper intended to highlight the importance of redox-flow batteries for future research. However, this estimation about redox-flow batteries was only drawn from the perspective of disruptive innovation while limited as it was based on an expert survey. It must therefore be enriched by further including technological, research perspectives.

Another future research avenue is the integration of further methods for prediction and evaluation of future technologies. These include, among others, the Delphi method, future-oriented technology analysis or future-oriented technology assessment [71-74]. Such methods can help to better understand and predict the underlying technological foundations, frame conditions and different forms of application for battery technologies in order to extend the findings of this paper.

In a broader context, future research could attempt to better understand the current initiatives in mobility and energy storage towards sustainability, and in manufacturing and digitization, often subsumed under the concept of Industry 4.0 [75-82]. 
Author Contributions: Conceptualization, J.M.M. and R.K.; Data curation, R.K.; Formal analysis, R.K.; Investigation, R.K.; Methodology, J.M.M. and R.K.; Project administration, J.M.M.; Supervision, J.M.M.; Validation, J.M.M. and R.K.; Visualization, J.M.M. and R.K.; Writing—original draft, J.M.M. and R.K.; Writing一review and editing, J.M.M.

Funding: This research received no external funding.

Conflicts of Interest: The authors declare no conflict of interest.

\section{Appendix A}

Table A1. Detailed answers of questionnaire (price, C).

\begin{tabular}{ccccc}
\hline \multirow{2}{*}{$\begin{array}{c}\text {... were cheaper than NimH/lithium-ion batteries } \\
\text { when introduced into the market. }\end{array}$} & \multicolumn{2}{c}{ Lithium-ion } & \multicolumn{2}{c}{ Redox-flow } \\
\cline { 2 - 5 } & Frequency & Percentage & Frequency & Percentage \\
\hline (a) Yes (lower price) & 3 & $6.7 \%$ & 17 & $34.7 \%$ \\
(b) No (higher price) & 42 & $93.3 \%$ & 32 & $65.3 \%$ \\
\hline Total & 53 & $100.0 \%$ & 49 & $100.0 \%$ \\
Mean & \multicolumn{2}{c}{0.07} & 0.35 \\
Standard deviation & \multicolumn{2}{c}{0.252} & 0.481 \\
\hline
\end{tabular}

Table A2. Detailed answers of questionnaire (lower attack, L).

\begin{tabular}{lcccc}
\hline \multirow{2}{*}{$\begin{array}{l}\text {... had/have a higher energy density when introduced into } \\
\text { the market (Wh/kg). }\end{array}$} & \multicolumn{2}{c}{ Lithium-ion } & \multicolumn{2}{c}{ Redox-flow } \\
\cline { 3 - 5 } & Frequency & Percentage & Frequency & Percentage \\
\hline Yes (upper market segment) & 46 & $88.5 \%$ & 13 & 26.5 \\
No (lower market segment) & 6 & $11.5 \%$ & 36 & 73.5 \\
\hline Total & 52 & $100.0 \%$ & 49 & $100.0 \%$ \\
Mean & \multicolumn{2}{c}{0.12} & 0.73 \\
Standard deviation & \multicolumn{2}{c}{0.323} & 0.446 \\
\hline
\end{tabular}

Table A3. Detailed answers of questionnaire (type of enterprise, E).

\begin{tabular}{ccccc}
\hline \multirow{2}{*}{$\begin{array}{c}\text { Companies from outside the battery industry have } \\
\text { driven its spread }\end{array}$} & \multicolumn{2}{c}{ Lithium-ion } & \multicolumn{2}{c}{ Redox-flow } \\
\cline { 2 - 5 } & Frequency & Percentage & Frequency & Percentage \\
\hline $\begin{array}{c}\text { Yes (pioneers) } \\
\text { No (established } \\
\text { enterprises) }\end{array}$ & 29 & $37.0 \%$ & 28 & $54.9 \%$ \\
\hline $\begin{array}{c}\text { Total } \\
\text { Mean }\end{array}$ & 46 & $63.0 \%$ & 23 & $45.1 \%$ \\
\hline Standard deviation & \multicolumn{2}{c}{0.63} & 51 & $100.0 \%$ \\
\hline
\end{tabular}

Table A4. Detailed answers of questionnaire (firm size, S).

\begin{tabular}{ccccc}
\hline $\begin{array}{l}\text { Companies that were especially founded for this } \\
\text { purpose have driven its spread }\end{array}$ & \multicolumn{2}{c}{ Lithium-ion } & \multicolumn{2}{c}{ Redox-flow } \\
\cline { 2 - 5 } & Frequency & Percentage & Frequency & Percentage \\
\hline $\begin{array}{c}\text { (a) Yes (small } \\
\text { enterprises) } \\
\text { (b) No (large } \\
\text { enterprises) }\end{array}$ & 29 & $63.0 \%$ & 14 & $28.0 \%$ \\
\hline $\begin{array}{c}\text { Total } \\
\text { Mean }\end{array}$ & 17 & $37.0 \%$ & 36 & $72.0 \%$ \\
\hline Standard deviation & 46 & $100.0 \%$ & 50 & $100.0 \%$ \\
\end{tabular}


Table A5. Detailed answers of questionnaire (change of technological performance, P).

\begin{tabular}{ccc}
\hline $\begin{array}{c}\text { To which percentage will energy density have } \\
\text { increased }(\mathrm{Wh} / \mathrm{kg}) \text { in the next ten years? }\end{array}$ & Lithium-ion & Redox-flow \\
\hline Valid & 51 & 48 \\
Mean & $50.53 \%$ & $36.96 \%$ \\
Standard deviation & 49.831 & 36.822 \\
\hline
\end{tabular}

Table A6. Detailed answers of questionnaire (time until market entrance of technology, T).

\begin{tabular}{ccccc}
\hline $\begin{array}{c}\text { In how many years will the } \\
\text { following battery technologies be } \\
\text { introduced on the market? }\end{array}$ & Redox-flow & NaS & Lithium-air & Zinc-air \\
\hline Valid & 53 & 47 & 47 & 45 \\
Mean & 9.66 years & 14.23 years & 16.94 years & 16.38 years \\
Standard deviation & 18.844 & 27.316 & 20.148 & 24.307 \\
\hline
\end{tabular}

\section{References}

1. Christensen, C.M. The Innovator's Dilemma: When New Technologies Cause Great Firms to Fail; Harvard Business School: Cambridge, MA, USA, 1997.

2. Danneels, E. Disruptive technology reconsidered: A critique and research agenda. J. Prod. Innov. Manag. 2004, 21, 246-258. [CrossRef]

3. Droege, S.; Johnson, N.B. Limitations of low-end disruptive innovation strategies. Int. J. Hum. Resour. Manag. 2010, 21, 242-259. [CrossRef]

4. Schmidt, G.M.; Druehl, C.T. When is a disruptive innovation disruptive? J. Prod. Innov. Manag. 2008, 25, 347-369. [CrossRef]

5. Zahra, S.A.; George, G. Absorptive capacity: A review, reconceptualization, and extension. Acad. Manag. Rev. 2002, 27, 185-203. [CrossRef]

6. Govindarajan, V.; Kopalle, P.K. Disruptiveness of innovations: Measurement and an assessment of reliability and validity. Strateg. Manag. J. 2006, 27, 189-199. [CrossRef]

7. Chen, C.; Zhang, J.; Guo, R.-S. The D-Day, V-Day, and bleak days of a disruptive technology: A new model for ex-ante evaluation of the timing of technology disruption. Eur. J. Oper. Res. 2016, 251, 562-574. [CrossRef]

8. Huang, X.; Sošić, G. Analysis of industry equilibria in models with sustaining and disruptive technology. Eur. J. Oper. Res. 2010, 207, 238-248. [CrossRef]

9. Sood, A.; Tellis, G.J. Demystifying disruption: A new model for understanding and predicting disruptive technologies. Mark. Sci. 2011, 30, 339-354. [CrossRef]

10. Govindarajan, V.; Kopalle, P.K. The usefulness of measuring disruptiveness of innovations ex-post in making ex ante predictions. J. Prod. Innov. Manag. 2006, 23, 12-18. [CrossRef]

11. Keller, A.; Hüsig, S. Ex ante identification of disruptive innovations in the software industry applied to web applications: The case of Microsoft's vs. Google's office applications. Technol. Forecast. Soc. Chang. 2009, 76, 1044-1054. [CrossRef]

12. Nagy, D.; Schuessler, J.; Dubinsky, A. Defining and identifying disruptive innovations. Ind. Mark. Manag. 2016, 57, 119-126. [CrossRef]

13. Dijk, M.; Wells, P.; Kemp, R. Will the momentum of the electric car last? Testing an hypothesis on disruptive innovation. Technol. Forecast. Soc. Chang. 2016, 105, 77-88. [CrossRef]

14. Hardman, S.; Steinberger-Wilckens, R.; van der Horst, D. Disruptive innovations: The case for hydrogen fuel cells and battery electric vehicles. Int. J. Hydrogen Energy 2013, 38, 15438-15451. [CrossRef]

15. Manyika, J.; Chui, M.; Bughin, J.; Dobbs, R.; Bisson, P.; Marrs, A. Disruptive Technologies: Advances that Will Transform Life, Business, and the Global Economy; McKinsey Global Institute: San Francisco, CA, USA, 2013.

16. He, X.; Delarue, E.; D'haeseleer, W.; Glachant, J.-M. A novel business model for aggregating the values of electricity storage. Energy Policy 2011, 39, 1575-1585. [CrossRef]

17. Wadia, C.; Albertus, P.; Srinivasan, V. Resource constraints on the battery energy storage potential for grid and transportation applications. J. Power Sources 2011, 196, 1593-1598. [CrossRef] 
18. Pinkse, J.; Bohnsack, R.; Kolk, A. The Role of Public and Private Protection in Disruptive Innovation: The Automotive Industry and the Emergence of Low-Emission Vehicles. J. Prod. Innov. Manag. 2014, 31, 43-60. [CrossRef]

19. Schumpeter, J.A. Socialism and Democracy; Harper: New York, NY, USA, 1942.

20. Foster, R.N. Innovation: The Attacker's Advantage; Summit Books: New York, NY, USA, 1988.

21. Henderson, R.M.; Clark, K.B. Architectural innovation: The reconfiguration of existing product technologies and the failure of established firms. Adm. Sci. Q. 1990, 35, 9-30. [CrossRef]

22. Adner, R. When are technologies disruptive? A demand-based view of the emergence of competition. Strateg. Manag. J. 2002, 23, 667-688.

23. Yu, D.; Hang, C.C. A reflective review of disruptive innovation theory. Int. J. Manag. Rev. 2010, 12, 435-452. [CrossRef]

24. Utterback, J.M.; Acee, H.J. Disruptive technologies: An expanded view. Int. J. Innov. Manag. 2005, 9, 1-17. [CrossRef]

25. Henderson, R. The innovator's dilemma as a problem of organizational competence. J. Prod. Innov. Manag. 2006, 23, 5-11. [CrossRef]

26. Christensen, C.; Raynor, M. The Innovator's Solution. Creating and Sustaining Successful Growth; Harvard Business Review: Cambridge, MA, USA, 2003.

27. Scrosati, B.; Garche, J. Lithium batteries: Status, prospects and future. J. Power Sources 2010, 195, $2419-2430$. [CrossRef]

28. Cox, D.R. Regression models and life tables (with discussion). J. R. Stat. Soc. 1972, 34, 187-220.

29. Altman, D.G.; Andersen, P.K. Bootstrap investigation of the stability of a cox regression model. Stat. Med. 1989, 8, 771-783. [CrossRef]

30. Cox, D.R.; Oakes, D. Analysis of Survival Data; CRC Press: Boca Raton, FL, USA, 1984.

31. Lillard, L.A. Simultaneous equations for hazards. J. Econom. 1993, 56, 189-217. [CrossRef]

32. Baker, J.N.; Collinson, A. Electrical energy storage at the turn of the Millennium. Power Eng. J. 1999, 13, 107-112. [CrossRef]

33. Chen, H.; Cong, T.N.; Yang, W.; Tan, C.; Li, Y. Progress in electrical energy storage system: A critical review. Prog. Nat. Sci. 2009, 19, 291-312. [CrossRef]

34. Hammami, A.; Raymond, N.; Armand, M. Lithium-ion batteries: Runaway risk of forming toxic compounds. Nature 2003, 424, 635-636. [CrossRef]

35. Offer, G.J.; Howey, D.; Contestabile, M.; Clague, R.; Brandon, N.P. Comparative analysis of battery electric, hydrogen fuel cell and hybrid vehicles in a future sustainable road transport system. Energy Policy 2010, 38, 24-29. [CrossRef]

36. Dunn, B.; Kamath, H.; Tarascon, J.-M. Electrical energy storage for the grid: A battery of choices. Science 2011, 334, 928-935. [CrossRef]

37. Doughty, D.H.; Butler, P.C.; Akhil, A.A.; Clark, N.H.; Boyes, J.D. Batteries for large-scale stationary electrical energy storage. Electrochem. Soc. Interface 2010, 19, 49-53. [CrossRef]

38. Kang, J.; Yan, F.; Zhang, P.; Du, C. Comparison of comprehensive properties of Ni-MH (nickel-metal hydride) and Li-ion (lithium-ion) batteries in terms of energy efficiency. Energy 2014, 70, 618-625. [CrossRef]

39. Emadi, A.; Lee, Y.J.; Rajashekara, K. Power Electronics and Motor Drives in Electric, Hybrid Electric, and Plug-In Hybrid Electric Vehicles. IEEE Trans. Ind. Electron. 2008, 55, 2237-2245. [CrossRef]

40. Luo, X.; Wang, J.; Dooner, M.; Clarke, J. Overview of current development in electrical energy storage technologies and the application potential in power system operation. Appl. Energy 2015, 137, 511-536. [CrossRef]

41. Akikur, R.K.; Saidur, R.; Ping, H.W.; Ullah, K.R. Comparative study of stand-alone and hybrid solar energy systems suitable for off-grid rural electrification: A review. Renew. Sustain. Energy Rev. 2013, 27, 738-752. [CrossRef]

42. Martinez-Laserna, E.; Sarasketa-Zabala, E.; Sarria, I.V.; Stroe, D.I.; Swierczynski, M.; Warnecke, A.; Timmermanns, J.; Goutam, S.; Omar, N.; Rodriguez, P. Technical Viability of Battery Second Life: A Study from the Ageing Perspective. IEEE Trans. Ind. Appl. 2018, 54, 2703-2713. [CrossRef]

43. Opitz, A.; Badami, P.; Shen, L.; Vignarooban, K.; Kannan, A.M. Can Li-Ion batteries be the panacea for automotive applications? Renew. Sustain. Energy Rev. 2017, 68, 685-692. [CrossRef] 
44. USCAR. USABC Goals for Advanced Batteries for EVs. Available online: http://www.uscar.org/commands/ files_download.php?files_id=364 (accessed on 25 November 2018).

45. Ibrahim, H.; Ilinca, A.; Perron, J. Energy storage systems-characteristics and comparisons. Renew. Sustain. Energy Rev. 2008, 12, 1221-1250. [CrossRef]

46. Oyama, N.; Tatsuma, T.; Sato, T.; Sotomura, T. Dimercaptan-polyaniline composite electrodes for lithium batteries with high energy density. Nature 1995, 373, 598-600. [CrossRef]

47. Alotto, P.; Guarnieri, M.; Moro, F. Redox flow batteries for the storage of renewable energy: A review. Renew. Sustain. Energy Rev. 2014, 29, 325-335. [CrossRef]

48. Crabtree, G.; Kócs, E.; Trahey, L. The energy-storage frontier. Lithium-ion batteries and beyond. MRS Bull. 2015, 40, 1067-1078. [CrossRef]

49. Hollister-Short, G. History of Technology; Bloomsbury Academic: London, UK, 2016; Volume 5.

50. Mohamed, M.R.; Sharkh, S.M.; Walsh, F.C. Redox flow batteries for hybrid electric vehicles: Progress and challenges. In Proceedings of the 5th IEEE Vehicle Power and Propulsion Conference, Dearborn, MI, USA, 7-10 September 2009.

51. Imanishi, N.; Luntz, A.C.; Bruce, P.G. The Lithium Air Battery: Fundamentals; Springer: New York, NY, USA, 2014.

52. Chandy, R.K.; Tellis, G.J. The incumbent's curse? Incumbency, size, and radical product innovation. J. Mark. 2000, 64, 1-17.

53. Wedege, K.; Bae, D.; Smith, W.A.; Mendes, A.; Bentien, A. Solar redox flow batteries with organic redox couples in aqueous electrolytes: A minireview. J. Phys. Chem. C 2018, 122, 25729-25740. [CrossRef]

54. Wedege, K.; Bae, D.; Dražević, E.; Mendes, A.; Vesborg, P.C.; Bentien, A. Unbiased, complete solar charging of a neutral flow battery by a single Si photocathode. RSC Adv. 2018, 8, 6331-6340. [CrossRef]

55. Abernathy, W.J.; Utterback, J.M. Patterns of industrial innovation. Technol. Rev. 1978, 80, 40-47.

56. Chen, M.-J.; Hambrick, D.C. Speed, stealth, and selective attack: How small firms differ from large firms in competitive behavior. Acad. Manag. J. 1995, 38, 453-482. [CrossRef]

57. Bergek, A.; Berggren, C.; Magnusson, T.; Hobday, M. Technological discontinuities and the challenge for incumbent firms: Destruction, disruption or creative accumulation? Res. Policy 2013, 42, 1210-1224. [CrossRef]

58. Hill, C.W.L.; Rothaermel, F.T. The performance of incumbent firms in the face of radical technological innovation. Acad. Manag. Rev. 2003, 28, 257-274. [CrossRef]

59. Lillard, L.A.; Panis, C. aML Frequently Asked Questions. Available online: http://www.applied-ml.com/ support/faq.html (accessed on 25 November 2018).

60. Krosnick, J.A.; Presser, S. Question and Questionnaire Design. Handbook of Survey Research; Elsevier: San Diego, CA, USA, 2010; pp. 263-314.

61. Veile, J.W.; Kiel, D.; Müller, J.M.; Voigt, K. Ecosystem 4.0: A Supply Chain Perspective on Business Model Innovation. In Proceedings of the XXX International Society for Professional Innovation Management (ISPIM) Innovation Conference, Florence, Italy, 16-19 September 2019.

62. Schmidt, M.-C.; Veile, J.W.; Müller, J.M.; Voigt, K.-I. Kick-start for connectivity-How to implement digital platforms successfully. In Proceedings of the XXX International Society for Professional Innovation Management (ISPIM) Innovation Conference, Florence, Italy, 16-19 September 2019.

63. Chandy, R.K.; Telis, G.J. Organizing for radical product innovation: The overlooked role of willingness to cannibalize. J. Mark. Res. 1998, 35, 474-487. [CrossRef]

64. Görbe, P.; Magyar, A.; Hangos, K.M. Reduction of power losses with smart grids fueled with renewable sources and applying EV batteries. J. Clean. Prod. 2012, 34, 125-137. [CrossRef]

65. Noack, J.; Wietschel, L.; Roznyatovskaya, N.; Pinkwart, K.; Tübke, J. Techno-economic modeling and analysis of redox flow battery systems. Energies 2016, 9, 627. [CrossRef]

66. Reinhardt, R.; Gurtner, S. The overlooked role of embeddedness in disruptive innovation theory. Technol. Forecast. Soc. Chang. 2018, 132, 268-283. [CrossRef]

67. Kilkki, K.; Mäntylä, M.; Karhu, K.; Hämmäinen, H.; Ailisto, H. A disruption framework. Technol. Forecast. Soc. Chang. 2018, 129, 275-284. [CrossRef]

68. Roy, R. Role of relevant lead users of mainstream product in the emergence of disruptive innovation. Technol. Forecast. Soc. Chang. 2018, 129, 314-322. [CrossRef] 
69. Chen, J.Y.; Hsieh, C.L.; Hsu, N.Y.; Chou, Y.S.; Chen, Y.S. Determining the limiting current density of vanadium redox flow batteries. Energies 2014, 7, 5863-5873. [CrossRef]

70. Zhang, X.; Li, Y.; Skyllas-Kazacos, M.; Bao, J. Optimal sizing of vanadium redox flow battery systems for residential applications based on battery electrochemical characteristics. Energies 2016, 9, 857. [CrossRef]

71. Yu, D.; Hang, C.C. Creating technology candidates for disruptive innovation: Generally applicable R\&D strategies. Technovation 2011, 31, 401-410.

72. Halicka, K.; Lombardi, P.A.; Styczyński, Z. Future-oriented analysis of battery technologies. In Proceedings of the IEEE International Conference on Industrial Technology (ICIT), Seville, Spain, 17-19 March 2015.

73. Haegeman, K.; Marinelli, E.; Scapolo, F.; Ricci, A.; Sokolov, A. Quantitative and qualitative approaches in Future-oriented Technology Analysis (FTA): From combination to integration? Technol. Forecast. Soc. Chang. 2013, 80, 386-397. [CrossRef]

74. Cagnin, C.; Havas, A.; Saritas, O. Future-oriented technology analysis: Its potential to address disruptive transformations. Technol. Forecast. Soc. Chang. 2013, 80, 379-385. [CrossRef]

75. Müller, J.M. Antecedents to Digital Platform Usage in Industry 4.0 by Established Manufacturers. Sustainability 2019, 11, 1121. [CrossRef]

76. Birkel, H.S.; Veile, J.W.; Müller, J.M.; Hartmann, E.; Voigt, K.-I. Development of a risk framework for Industry 4.0 in the context of sustainability for established manufacturers. Sustainability 2019, 11, 384.

77. Müller, J.M. Business model innovation in small- and medium-sized enterprises. Strategies for industry 4.0 providers and users. J. Manuf. Technol. Manag. 2019. [CrossRef]

78. Müller, J.M.; Däschle, S. Business Model Innovation of Industry 4.0 Solution Providers Towards Customer Process Innovation. Processes 2018, 6, 260. [CrossRef]

79. Veile, J.W.; Kiel, D.; Müller, J.M.; Voigt, K.-I. Lessons learned from Industry 4.0 implementation in the German manufacturing industry. J. Manuf. Technol. Manag. 2019. [CrossRef]

80. Muller, J.M.; Kiel, D.; Voigt, K.-I. What Drives the Implementation of Industry 4.0? The Role of Opportunities and Challenges in the Context of Sustainability. Sustainability 2018, 10, 247. [CrossRef]

81. Zeng, Y.; Huang, Z.; Cai, Y.; Liu, Y.; Xiao, Y.; Shang, Y. A Control Strategy for Driving Mode Switches of Plug-in Hybrid Electric Vehicles. Sustainability 2018, 10, 4237. [CrossRef]

82. Xie, S.; Hu, X.; Lang, K.; Qi, S.; Liu, T. Powering Mode-Integrated Energy Management Strategy for a Plug-In Hybrid Electric Truck with an Automatic Mechanical Transmission Based on Pontryagin's Minimum Principle. Sustainability 2018, 10, 3758. [CrossRef] 